\title{
Design of decision support system in determining the single student tuition fee in higher education
}

\author{
Muhammad Anwar ${ }^{\left.1^{*}\right)}$, Elsa Sabrina ${ }^{2}$ \\ ${ }^{12}$ Universitas Negeri Padang, Indonesia \\ *)Corresponding author, ఏe-mail: muh_anwar@ft.unp.ac.id
}

\begin{abstract}
This study aims to design an application in determining the single student tuition fee using the Analytical Hierarchy Process method in Higher Education. Universitas Negeri Padang has used a system to carry out the process of grouping in Single Tuition Fee (STF), but there are still many deficiencies in determining variables. The stages in this research begin with problem analysis, needs analysis, implementation, and testing. This system architecture is based on Model-View-Controller using the Yii2 framework with the PHP programming language. This system uses the Analytical Hierarchy Process method which has a calculation of the consistency value in determining the priority level of the criteria. Determination of criteria based on a number of criteria and a number of alternatives. The results of this study provide a ranking system for each alternative. The highest-ranking is the main priority in the system in making decisions by looking at the student's economic condition.
\end{abstract}

Keywords: Student, higher education, single tuition fee, model view controller, yii2.

How to Cite: Anwar, M., \& Sabrina, E. (2020). Design of decision support system in determining the single student tuition fee in higher education. COUNS-EDU: The International Journal of Counseling and Education, 5(4), 185-195. DOI: org/10.23916/0020200531440

This is an open access article distributed under the Creative Commons Attribution License, which permits unrestricted use distribution, and reproduction in any medium, provided the original work is properly cited. (C2020 by author.

\section{Introduction}

Education is part of the national education system which has a very strategic role in the efforts to educate the nation's life and advance science and technology. In an effort to increase competitiveness in the current global era, higher education is needed to produce human resources who are intelligent, creative, and have character (Sujana, 2019). To improve the quality of education, a driving aspect is needed, namely operational costs (budget). The operational cost of education is one of the supporting factors for the development of the quality of education. Currently PTN is developing new innovations by implementing the Single Tuition Fee (STF) classification system, with the hope of helping the poor to continue to higher education (Rokhman, Rozi, and Asmara, 2017; Efendi, Andreswari, and Barus, 2017).

The existence of the STF system is based on a Circular from the Higher Education which is the basis for implementing STF, namely Circular Number 97 / E / KU / 2013 concerning Single Tuition Fees which contains a request from the Director General of Higher Education. Dikti to PTN leaders to eliminate entry fees and implement Single Tuition Fee for new students of regular undergraduate programs starting in the 2013/2014 academic year (Purnama, Sitorus, and Diponegoro 2019). Single Tuition Fee (STF) is a system applied to financing lectures that must be borne by State University students who are under the Ministry of Research, Technology and Higher Education (Aviani and Hidayat, 2020; Wawan Firgiawan, Nuralamsah Zulkarnaim, 2019). In this case, the tuition fee is not like in previous times where the tuition fee for students consists of several separate components, for example tuition fees, practicum 
fees, student parent contributions, thesis examination fees, graduation fees, donations for improving the quality of education, and others (Aviani and Hidayat, 2020). Single tuition fees consist of seven groups, namely STF 1 (one) group, STF 2 (two) groups, STF 3 (three) groups, STF 4 (four) groups, STF 5 (five) groups, STF 6 (six) groups and group 7 (seven) whose nominal value varies. Based on the problems in determining the single tuition group, it is necessary to build a system that is able to determine single tuition groups automatically (Rokhman, Rozi, and Asmara, 2017).

Universitas Negeri Padang has used the system in the process of determining student STF. However, in the implementation process there were still many deficiencies, such as the number of student STFs that were not in accordance with the economic situation and conditions due to the lack of detailed variables. Based on the problems described above, a method is needed that needs to be applied to solve the problem of determining STF at Universitas Negeri Padang. The Analytic Hierarchy Process (AHP) is a measurement theory through pairwise comparisons and relying on expert judgment to lower the priority scale (Novianti, 2019; Jazuli, 2016). Relative scale measurement is in qualitative form. Comparisons use absolute judgments and are compared between one element and another (Jazuli, 2016; Putra, 2019).

AHP (Analytial Hierarchy Process) is used to obtain the ratio scale of several discrete or continuous pair matches. Pairwise comparisons can be obtained through actual measurements as well as relative measurements of the level of liking, importance, or feeling (Rahma and Anwar, 2021). The AHP method is a decision support system method that describes complex problems into several simpler levels of hierarchical problems, making it easier to analyze in a built system (Tasrif et al, 2021; Novianti, 2019). The first level in the AHP method is the main objective of the DSS, then the second level is in the form of criteria, and the third level is in the form of candidates (Tasrif et al, 2021; Efendi, Andreswari, and Barus, 2017). In the AHP method, criteria level data will be used to compare the information obtained from each candidate in realizing the main goal of helping decision making in solving a problem (Tasrif et al, 2021). And it is hoped that the AHP (Analytical Hierarchy Process) method can help the faculty coordinator in determining student STF.

\section{Method}

Based on a system development method using a Decision Support System (DSS). Decision Support System (DSS) is a computer-based system designed to improve and support the effectiveness of decision making in solving semi-structured and unstructured problems (Purnama, Sitorus, and Diponegoro, 2019; Nur, Andani, and Poningsih, 2018; Sendana, Wibawa, and Sutikno, 2014; Raya, 2013). Decision Support System (DSS) as a computer-based interactive system that helps decision makers utilize data and models to solve unstructured problems (Raya, 2013; Purnama, Sitorus, and Diponegoro, 2019). At this stage the writer will conduct a system analysis with 4 phases contained in the SPK, namely: 1) intelligence phase, 2) design phase, 3) selection phase and 4) action implementation phase (Imbar, Masli, and Edi, 2016; Jazuli, 2016; Putra, 2019).

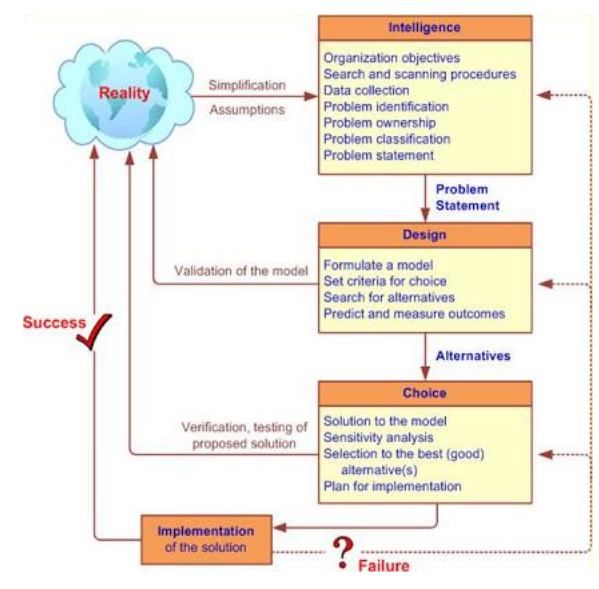

Figure 1. Stages of the decision support system model (Source: google.com) 
This analysis stage involves filling out a questionnaire on the system created (Ganefri et al. 2020; Imbar, Masli, and Edi, 2016). Several items were asked of students regarding family data and family economic conditions as described in Figure 2. In this process, students were asked to fill out a questionnaire using the answer options that had been determined as sub-criteria. This means that from this questionnaire the information is used to help obtain decisions about the student's STF.

\section{System Analysis}

System analysis is the process of solving a complete system into several components of the system itself, with the aim of identifying and evaluating the opportunities, problems, and obstacles that exist in the system so that solutions will emerge for improvement (Rokhman, Rozi, and Asmara, 2017; Nur , Andani, and Poningsih, 2018).

\section{Current System Analysis}

The conclusion of the ongoing system analysis is that the determination of STF for Universitas Negeri Padang students has used the system but there are still many shortcomings such as the number of STF students who are not in accordance with economic conditions and conditions due to a lack of detailed descriptions of the variables.

\section{System Analysis Proposed}

Based on the analysis of the problems obtained, a decision support system is proposed in determining the STF of Universitas Negeri Padang Students.

\section{System Planning}

System design is a set of activities that describe in detail how the system will run. The system design is a modified result of the analysis which will be implemented later (Novianti, 2019).

This program applies the Analitycal Hierarchy Process (AHP) method to produce the number of STF students in the form of an assessment. Each stage of the prioritization process based on criteria using the analitycal hierarchy process (AHP) method will be described sequentially (Determination et al. 2020; Novianti, 2019). The stages are as follows: 1) Identify problems and desired goals, select then sort according to predetermined criteria (Determination et al. 2020); 2) In Figure 2, there are thirty-seven criteria data that will be used to determine student STF. All of these criteria are the basis for determining the priority order for determining STF. These criteria consist of Father's Last Education (C1), Father's Main Job (C2), Income from Father's Main Job (C3), Income from Father's Side Job (C4), Father's Status (C5), Mother's Last Education (C6), Occupation. Main Mother (C7), Income from Mother's Main Job (C8), Income from Mother's Side Work (C9), Mother Status (C10), Relationship with Prospective Students (C11), Children Who are Currently Studying (C12), Children Who Are in School (C13), Home Ownership Status (14), Number of Houses (C15), House Land Area (C16), House Building Area (C17), PBB Bill (C18), MCK (C19), Distance from house to city center (C20), Number of people who lived in the last 6 months (C21), House in IDT (C22), Power source (C23), Electricity (C24), Average electricity payment for the last 6 months (C25), Average bill payments telephone / internet for the last 6 months (C26), Average TV bill payments for the last 6 months (C27), Number of cars owned (C28), Total car PKB tax payments (C29), Number of motorbikes owned (C30), total motorcycle PKB tax payments (C31), total assets owned (C32), study plans (C33), family support (C34), transportation from the area of origin to Padang (C35), transportation daily during college (C36) and Estimated transportation costs (C37). Each criterion in the data variable that determines STF has a value based on the level of data the student has. These levels are presented in table 2; 3) Grouping criteria into a hierarchy. 


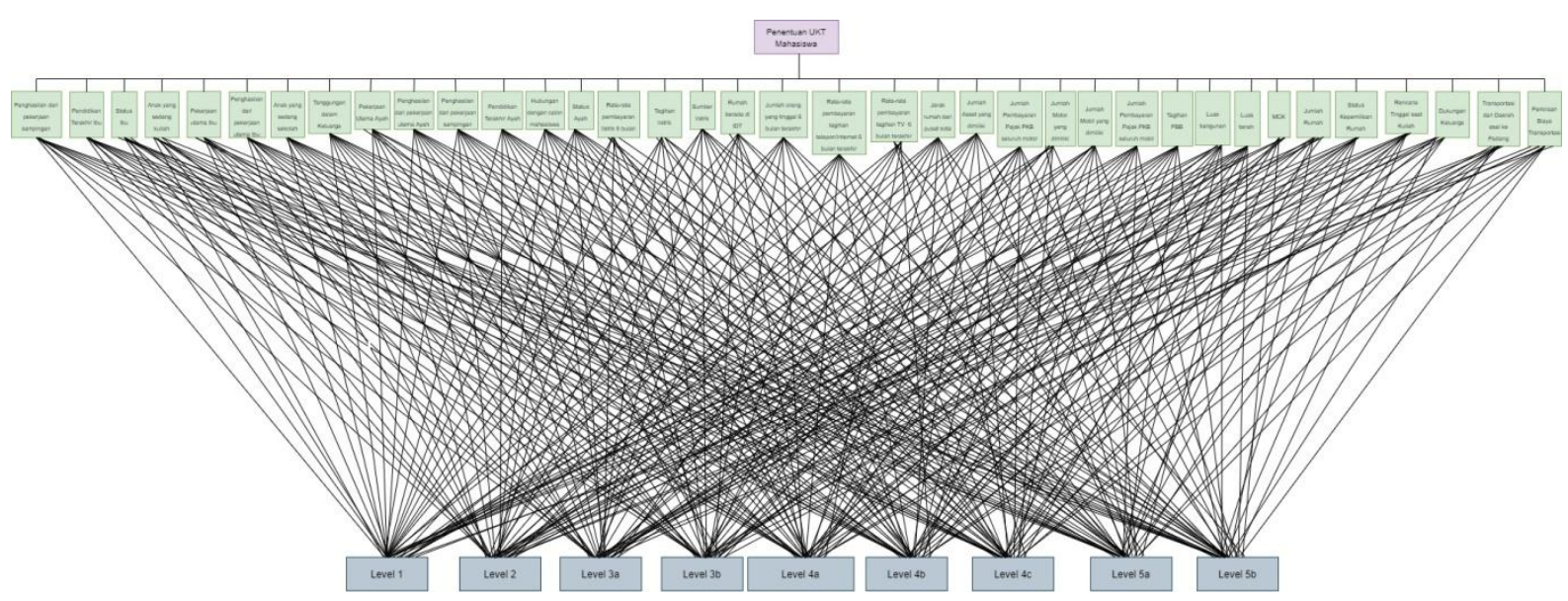

Figure 2. Hierarchy of criteria grouping

Alternatives are objects that have the same opportunity to be selected by decision makers, in this case as STF recipients. The following alternatives can be selected:

Table 1. Alternative Prospective STF Recipients

\begin{tabular}{ccc}
\hline Alternative & Number of STF & Final Score \\
1 & Rp. 500.000 & $41-42$ \\
2 & Rp. 1.000 .000 & $>42-<=49$ \\
3A & Rp. 2.000 .000 & $>=50-<=57$ \\
3B & Rp. 2.500 .000 & $>=58-<=65$ \\
4A & Rp. 3.000 .000 & $>=66-<=70$ \\
4C & Rp. 3.500 .000 & $>=71-<=75$ \\
5A & Rp. 4.000 .000 & $>=76-<=80$ \\
5B & Rp. 4.500 .000 & $>=81$ \\
\hline
\end{tabular}

\section{Results and Discussions}

Higher education in financial system development must provide the best service to all students. The ease with which students are given will have an impact on improving the quality of the campus and as a good promotion in the future. It is hoped that the alternative design of a single quality cash payment application will be able to answer the obstacles that have occurred so far. Can the results of this design start from the design of the user interface, then apply the design in a program code so that it displays a layout. The layout view makes it easier to interact with the overall system interface. Following are the results of database design and display design in the Decision Support System in Determining STF for UNP Students.

\section{Use Case Diagram}

The use case diagram illustrates how users can interact with the system (Avila and Kurniadi 2021). The actors of this system consist of admins, students and vice deans II. The following use case diagram displays can be seen in the figure: 


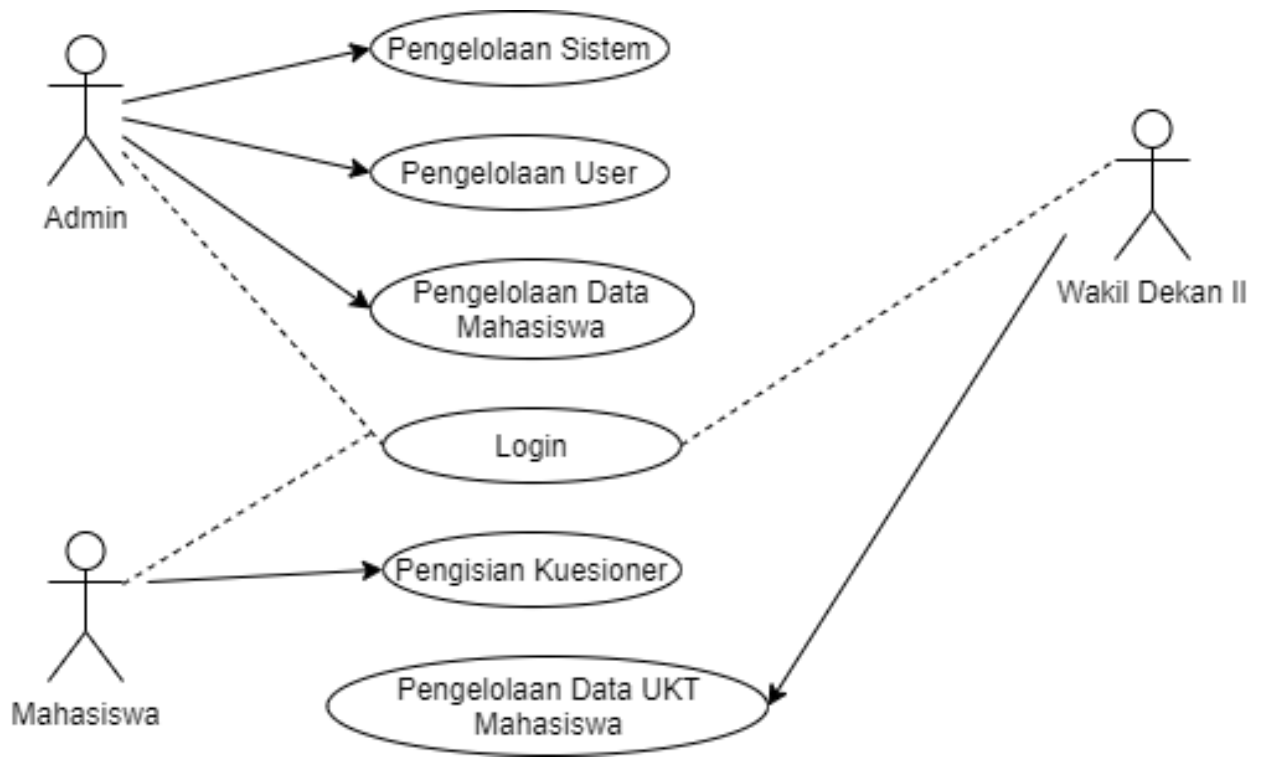

Figure 3. Use Case Diagram

\section{ERD (Entity Relationship Diagram)}

Entity Relationship Diagram (ERD) is a data model developed based on objects (Avila and Kurniadi 2021). ERD is divided into 3 components, namely entities, attributes and relationships. The following shows the ERD used in this system.

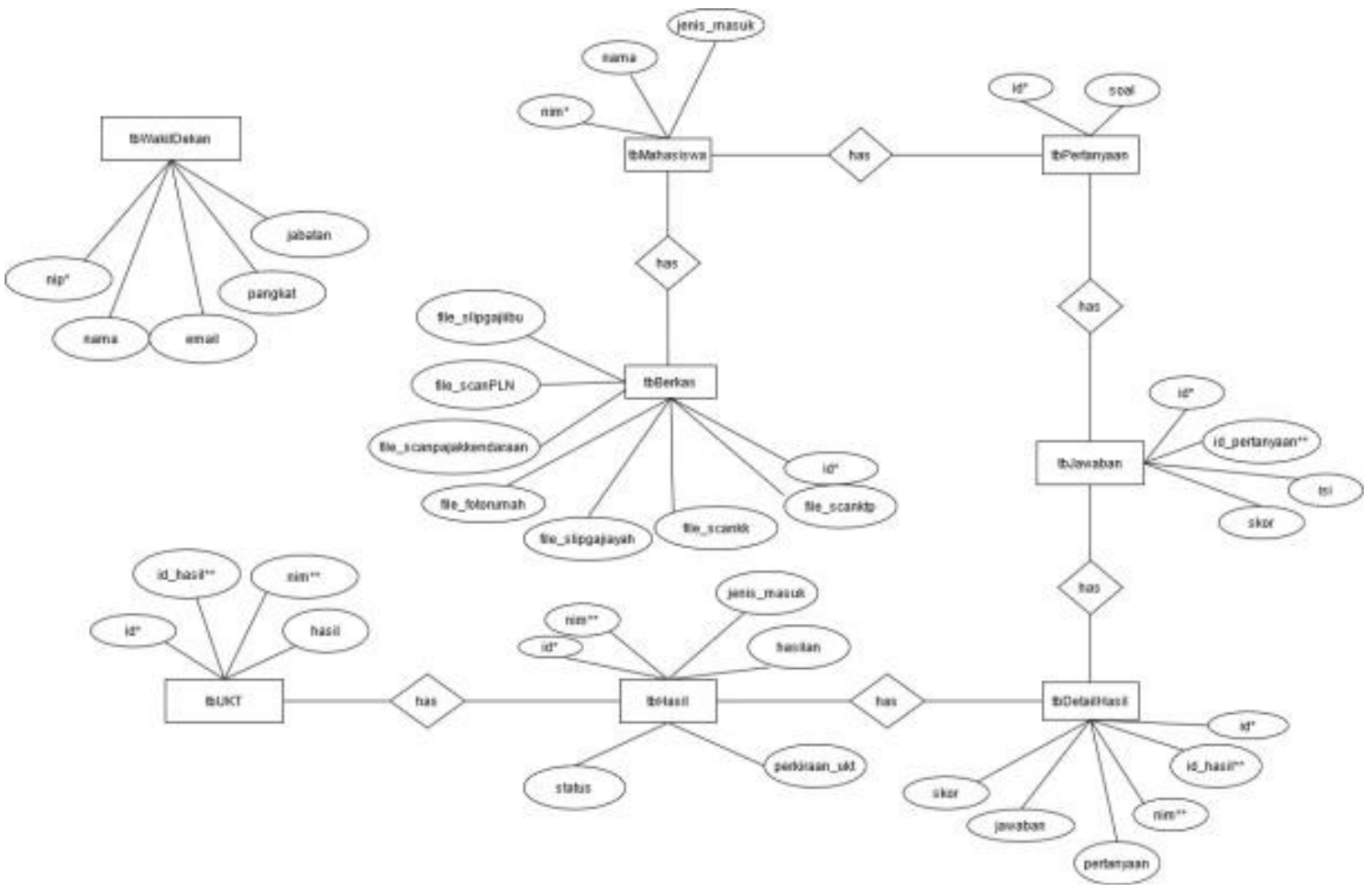

Figure 4. Entity Relationship Diagram (ERD)

In programming, there are several things that must be considered, one of which is the PHP and Mysql programming languages which later can be used to run properly. 


\section{Context Diagram}

Context diagram is a diagram that describes the relationship between all inputs to the system and all outputs from the system (Novianti 2019; Avila and Kurniadi 2021).

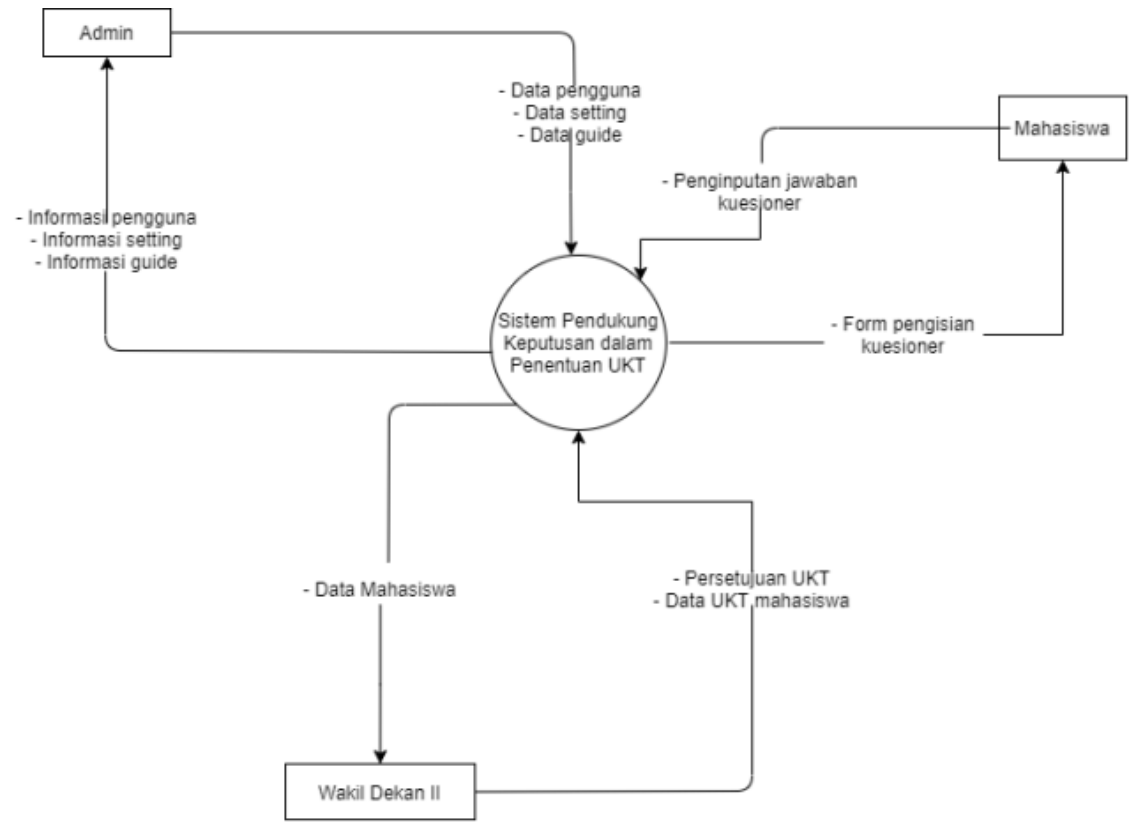

Figure 5. Context Diagram

\section{Login page}

The login page is the main page when accessing this system (Avila and Kurniadi 2021). This page functions to enter the system using a username and password.

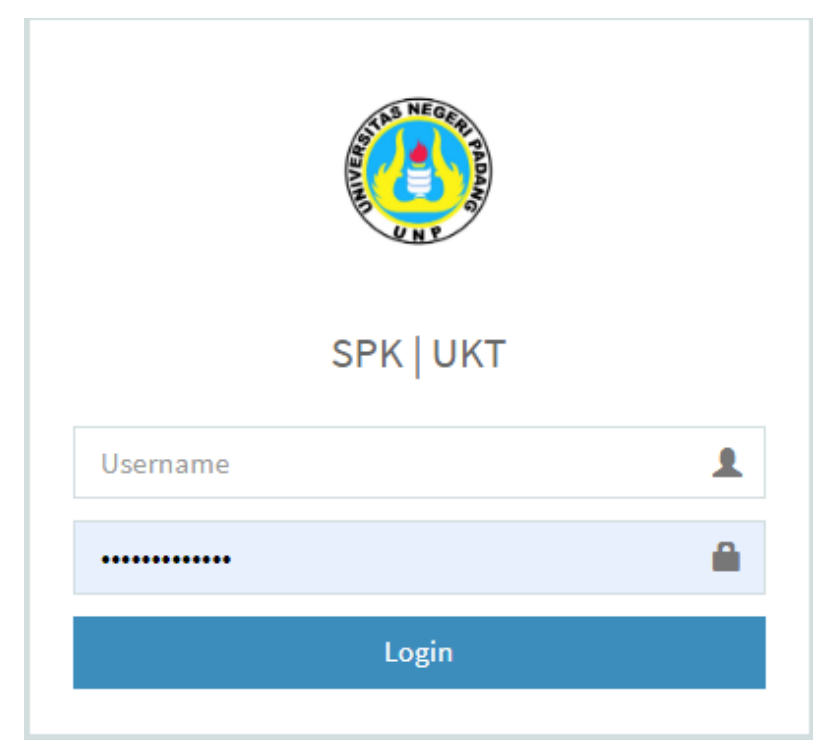

Figure 6. Login page 


\section{Main page}

After successful login, each user will enter the main page. The main page for admin functions to display menus that can be accessed by accounts that have admin access.

Admin

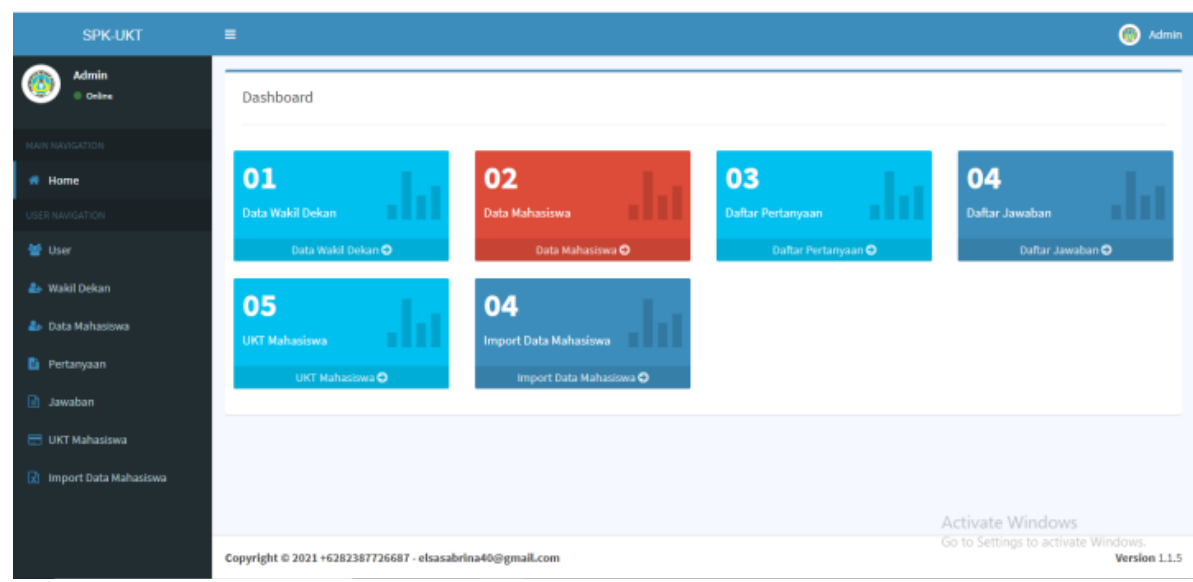

Figure 7. Admin Main Page

\section{Deputy Dean II}

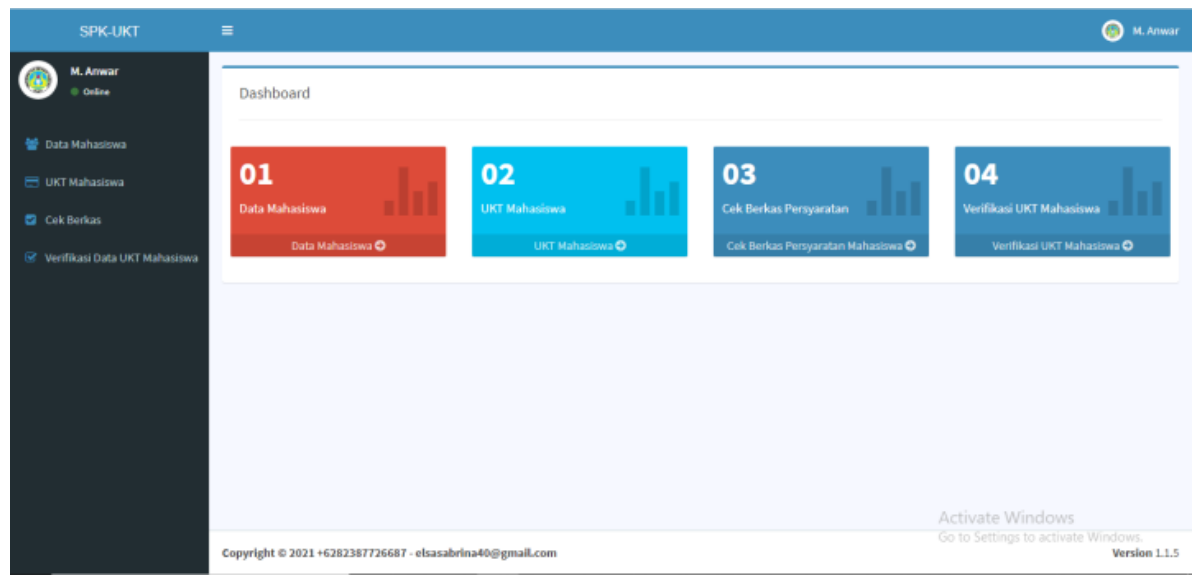

Figure 8. Main page of the Vice Dean II 


\section{Collage student}

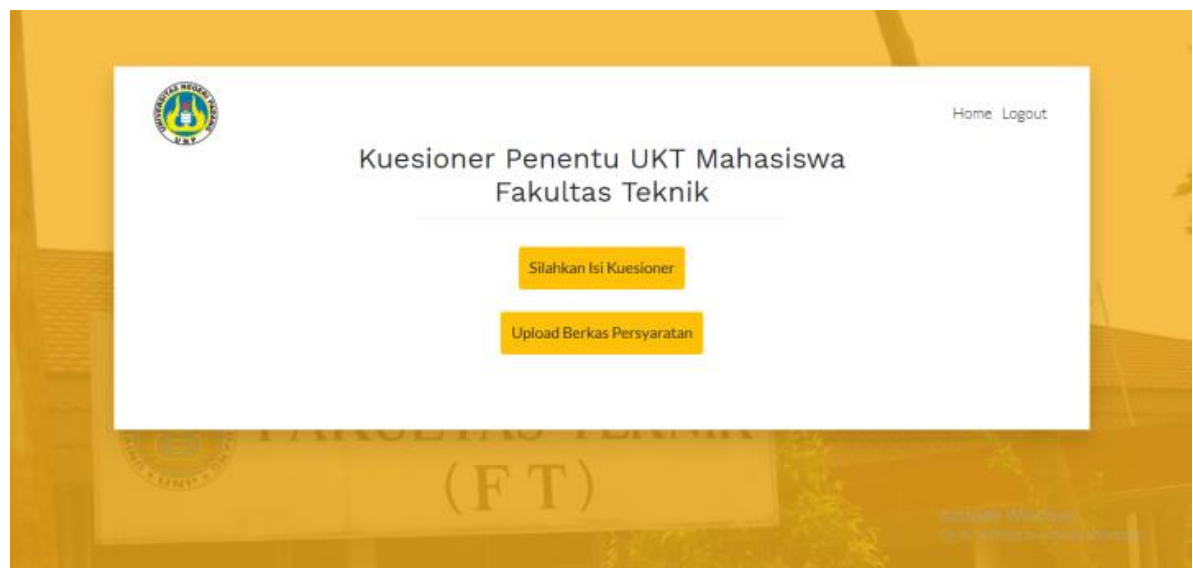

Figure 9. Student Main Page

\section{STF verification form}

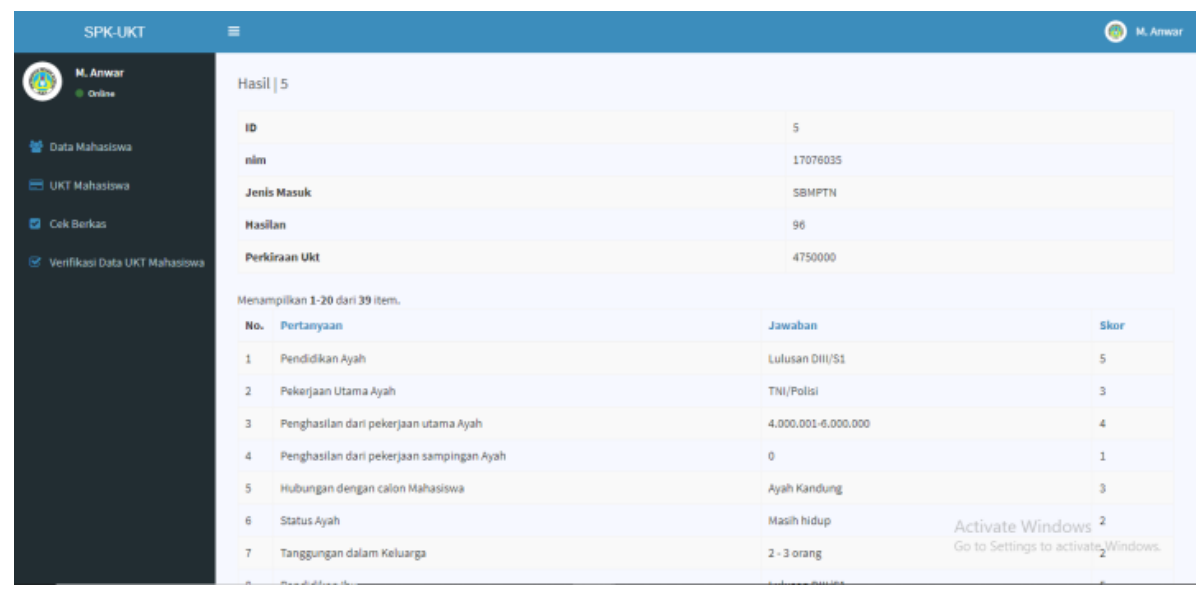

Figure 10. STF Verification Form

\section{STF Rejection Form}

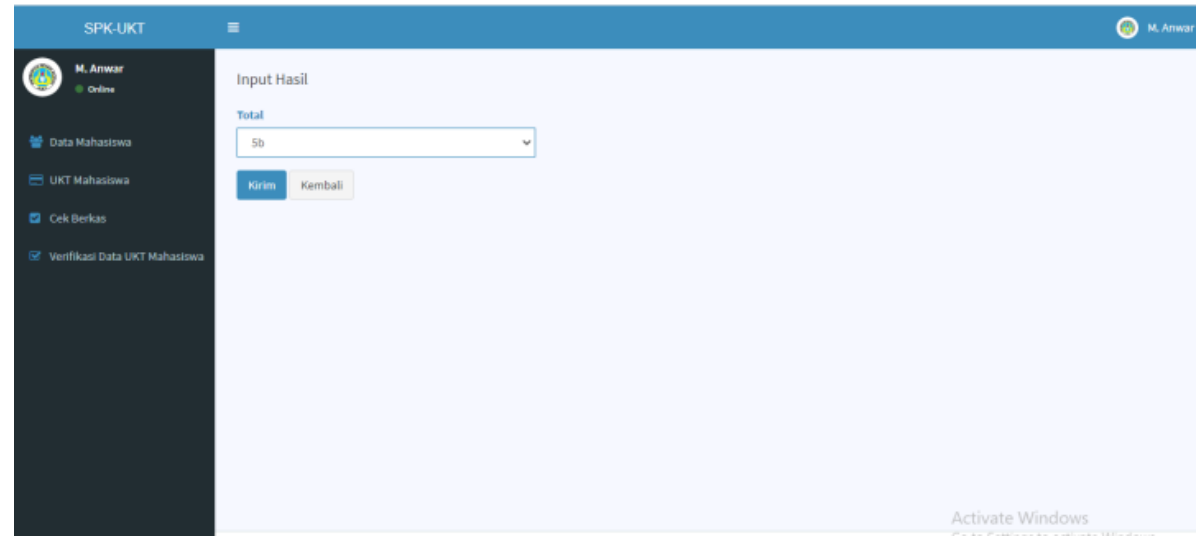

Figure 11. STF Rejection Form 


\section{STF Info Form}

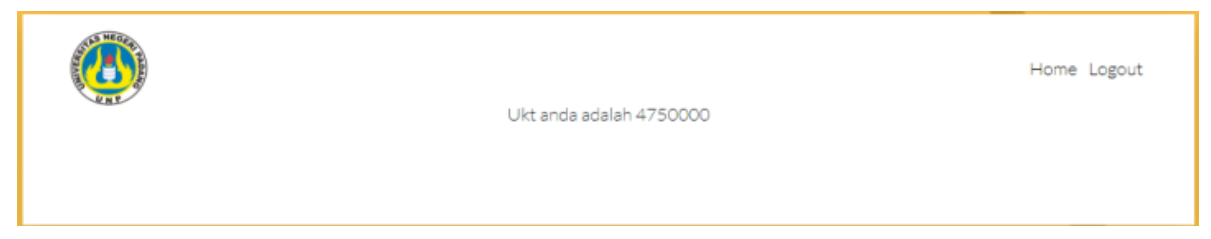

Figure 12. STF Info Form

\section{Conclusions}

Based on the research that has been done, the process of determining the Single Student Tuition Fee (STF) will be easy to determine if you use a system created with a Decision Support System using the AHP method. Where this method can determine the weight of each sub-criteria that will get the STF results.

\section{References}

Aviani, Tri Hasanah Bimastari, and Asep Toyib Hidayat. 2020. "Sistem Pendukung Keputusan Seleksi Pemberian Uang Kuliah Tunggal Menerapkan Metode WASPAS." Jurnal Sistem Komputer Dan Informatika (JSON) 2 (1): 102-9. https://doi.org/10.30865/json.v2i1.2482.

Avila, Marzella Aurelia, and Denny Kurniadi. 2021. "Rancang Bangun Sistem Informasi E-Office Pada Tata Usaha Fakultas Teknik Universitas Negeri Padang Konsep Electronic Office ( e-Office ) Konsep Sistem Informasi Administrasi Perkantoran Analisis Sistem Berjalan P - ISSN : 2302-3295” 9 (1).

Efendi, Rusdi, Desi Andreswari, and Imanuel Barus. 2017. "Sistem Pendukung Keputusan Penentuan Uang Kuliah Tunggal Dengan Menggunakan Metode Weighted Product," no. September.

Ganefri, Ganefri, Hendra Hidayat, Asmar Yulastri, and Ifdil Ifdil. 2020. "The Need Analysis of the Production Based Entrepreneurship Training Model: Learning Entrepreneurship in Higher Education." COUNS-EDU: The International Journal of Counseling and Education 5 (3): 58-63. https://doi.org/10.23916/0020200528530.

Imbar, Radiant Victor, Kevin Masli, and Doro Edi. 2016. "Sistem Pendukung Keputusan Penerima Beasiswa Dengan Metode Simple Additive Weighting (Studi Kasus Di Fakultas Teknologi Informasi U.K. Maranatha)." Jurnal Teknik Informatika Dan Sistem Informasi 2 (3): 275-86. https://doi.org/10.28932/jutisi.v2i3.494.

Jazuli, Muhammad. 2016. "Sistem Pendukung Keputusan Penentuan Kelompok Uang Kuliah Tunggal Menggunakan Metode K-Means Clustering SKRIPSI Oleh :"

Novianti, Hardini. 2019. "Sistem Pendukung Keputusan Penentuan Uang Kuliah Tunggal Dengan Metode Analitical Hierarchy Process (Ahp) Di Universitas Sriwijaya." JSI: Jurnal Sistem Informasi (EJournal) 11 (1): 978-79. https://doi.org/10.36706/jsi.v11i1.9488.

Nur, Khairun Nisa Arifin, Sundari Retno Andani, and Poningsih Poningsih. 2018. "Sistem Pendukung Keputusan Pemilihan Operator Seluler Menggunakan Metode Multi-Objective Optimization on the Basis of Ratio Analysis (Moora)." KOMIK (Konferensi Nasional Teknologi Informasi Dan Komputer) 2 (1): 61-65. https://doi.org/10.30865/komik.v2i1.942.

Purnama, Mia, Sampe Hotlan Sitorus, and Muhammad Diponegoro. 2019. "Sistem Pendukung Keputusan Penentuan Kelompok Uang Kuliah Tunggal Menggunakan Metode Topsis Dengan Pembobotan Metode Ranking." Jurnal Komputer Dan Aplikasi 07 (02).

Putra, Reza Ade. 2019. "Penerapan Naïve Bayes Classifier Dengan Gaussian Function Untuk Menentukan Kelompok STF." Jurnal Ilmiah Informatika Global 9 (2): 112-17. https://doi.org/10.36982/jig.v9i2.583.

Rahma, Oktavia Suci, and Muhammad Anwar. 2021. "Perancangan Aplikasi Pemilihan Dosen Pembimbing Tugas Akhir Dengan Metode Analytical Hierarchy Process Jurusan Teknik Elektronika Universitas Negeri Padang a . Analisis Proses Bisnis Analisis Sistem 1 . Analisis Sistem Berjalan P ISSN : 2302-3295" 9 (1).

Raya, Universitas Palangka. 2013. "Implementasi Metode Simple Adaptive Weighted Pada Spk STF Universitas Palangka Raya 1.” 
Rokhman, Syaiful, Imam Fahrur Rozi, and Rosa Andrie Asmara. 2017. "Pengembangan Sistem Penunjang Keputusan Penentuan STF Mahasiswa Dengan Menggunakan Metode Moora Studi Kasus Politeknik Negeri Malang." Jurnal Informatika Polinema 3 (4): 36. https://doi.org/10.33795/jip.v3i4.41.

Sendana, Stefanus, Helmie Arif Wibawa, and Sutikno. 2014. "Sistem Penentuan Kelompok Uang Tunggal Di Universitas Diponegoro." Seminar Nasional Ilmu Komputer Undip, 91-96.

Sujana, I Wayan Cong. 2019. "Fungsi Dan Tujuan Pendidikan Indonesia." Adi Widya: Jurnal Pendidikan Dasar 4 (1): 29. https://doi.org/10.25078/aw.v4i1.927.

Tasrif, Elfi, Hadi Kurnia Saputra, Denny Kurniadi, Hendra Hidayat, and Akrimullah Mubai. 2021. "Designing Website-Based Scholarship Management Application for Teaching of Analytical Hierarchy Process ( AHP ) in Decision Support Systems ( DSS ) Subjects" 15 (09): 179-91.

Wawan Firgiawan, Nuralamsah Zulkarnaim, Sugiarto Cokrowibowo. 2019. "Komparasi Algoritma SAW, AHP, Dan TOPSIS Dalam Penentuan Uang Kuliah Tunggal (STF)." Universitas Sulawesi Barat 1 (2): 11. https://doi.org/10.31605/jcis.v2i1.

Aviani, Tri Hasanah Bimastari, and Asep Toyib Hidayat. 2020. "Sistem Pendukung Keputusan Seleksi Pemberian Uang Kuliah Tunggal Menerapkan Metode WASPAS." Jurnal Sistem Komputer Dan Informatika (JSON) 2 (1): 102-9. https://doi.org/10.30865/json.v2i1.2482.

Avila, Marzella Aurelia, and Denny Kurniadi. 2021. "Rancang Bangun Sistem Informasi E-Office Pada Tata Usaha Fakultas Teknik Universitas Negeri Padang Konsep Electronic Office ( e-Office ) Konsep Sistem Informasi Administrasi Perkantoran Analisis Sistem Berjalan P - ISSN : 2302-3295" 9 (1).

Efendi, Rusdi, Desi Andreswari, and Imanuel Barus. 2017. "Sistem Pendukung Keputusan Penentuan Uang Kuliah Tunggal Dengan Menggunakan Metode Weighted Product," no. September.

Ganefri, Ganefri, Hendra Hidayat, Asmar Yulastri, and Ifdil Ifdil. 2020. "The Need Analysis of the Production Based Entrepreneurship Training Model: Learning Entrepreneurship in Higher Education." COUNS-EDU: The International Journal of Counseling and Education 5 (3): 58-63. https://doi.org/10.23916/0020200528530.

Imbar, Radiant Victor, Kevin Masli, and Doro Edi. 2016. "Sistem Pendukung Keputusan Penerima Beasiswa Dengan Metode Simple Additive Weighting (Studi Kasus Di Fakultas Teknologi Informasi U.K. Maranatha)." Jurnal Teknik Informatika Dan Sistem Informasi 2 (3): 275-86. https://doi.org/10.28932/jutisi.v2i3.494.

Jazuli, Muhammad. 2016. "Sistem Pendukung Keputusan Penentuan Kelompok Uang Kuliah Tunggal Menggunakan Metode K-Means Clustering SKRIPSI Oleh :"

Novianti, Hardini. 2019. "Sistem Pendukung Keputusan Penentuan Uang Kuliah Tunggal Dengan Metode Analitical Hierarchy Process (Ahp) Di Universitas Sriwijaya." JSI: Jurnal Sistem Informasi (EJournal) 11 (1): 978-79. https://doi.org/10.36706/jsi.v11i1.9488.

Nur, Khairun Nisa Arifin, Sundari Retno Andani, and Poningsih Poningsih. 2018. "Sistem Pendukung Keputusan Pemilihan Operator Seluler Menggunakan Metode Multi-Objective Optimization on the Basis of Ratio Analysis (Moora)." KOMIK (Konferensi Nasional Teknologi Informasi Dan Komputer) 2 (1): 61-65. https://doi.org/10.30865/komik.v2i1.942.

Penentuan, Sistem, Nilai Uang, Kuliah Tunggal, Muhammad Agung, Jumadi Mabe Parenreng, Abdul Wahid, M Syahid Nur Wahid, Suhendhar Aji Putra, and Muhammad Mahdinul Bahar. 2020. "Mahasiswa Baru Universitas Negeri Makassar" 01 (April): 9-17.

Purnama, Mia, Sampe Hotlan Sitorus, and Muhammad Diponegoro. 2019. "Sistem Pendukung Keputusan Penentuan Kelompok Uang Kuliah Tunggal Menggunakan Metode Topsis Dengan Pembobotan Metode Ranking." Jurnal Komputer Dan Aplikasi 07 (02).

Putra, Reza Ade. 2019. "Penerapan Naïve Bayes Classifier Dengan Gaussian Function Untuk Menentukan Kelompok STF." Jurnal Ilmiah Informatika Global 9 (2): 112-17. https://doi.org/10.36982/jig.v9i2.583.

Rahma, Oktavia Suci, and Muhammad Anwar. 2021. "Perancangan Aplikasi Pemilihan Dosen Pembimbing Tugas Akhir Dengan Metode Analytical Hierarchy Process Jurusan Teknik Elektronika Universitas Negeri Padang a . Analisis Proses Bisnis Analisis Sistem 1. Analisis Sistem Berjalan P ISSN : 2302-3295" 9 (1).

Raya, Universitas Palangka. 2013. "Implementasi Metode Simple Adaptive Weighted Pada Spk STF Universitas Palangka Raya 1."

Rokhman, Syaiful, Imam Fahrur Rozi, and Rosa Andrie Asmara. 2017. "Pengembangan Sistem Penunjang Keputusan Penentuan STF Mahasiswa Dengan Menggunakan Metode Moora Studi 
Kasus Politeknik Negeri Malang." Jurnal Informatika Polinema $3 \quad$ (4): 36. https://doi.org/10.33795/jip.v3i4.41.

Sendana, Stefanus, Helmie Arif Wibawa, and Sutikno. 2014. "Sistem Penentuan Kelompok Uang Tunggal Di Universitas Diponegoro." Seminar Nasional Ilmu Komputer Undip, 91-96.

Sujana, I Wayan Cong. 2019. "Fungsi Dan Tujuan Pendidikan Indonesia." Adi Widya: Jurnal Pendidikan Dasar 4 (1): 29. https://doi.org/10.25078/aw.v4i1.927.

Tasrif, Elfi, Hadi Kurnia Saputra, Denny Kurniadi, Hendra Hidayat, and Akrimullah Mubai. 2021. "Designing Website-Based Scholarship Management Application for Teaching of Analytical Hierarchy Process ( AHP ) in Decision Support Systems ( DSS ) Subjects" 15 (09): 179-91.

Wawan Firgiawan, Nuralamsah Zulkarnaim, Sugiarto Cokrowibowo. 2019. "Komparasi Algoritma SAW, AHP, Dan TOPSIS Dalam Penentuan Uang Kuliah Tunggal (STF)." Universitas Sulawesi Barat 1 (2): 11. https://doi.org/10.31605/jcis.v2i1. 